\title{
Testing mathematical uranium migration models in combined ESR/U-series dating of fossil teeth from open-air sites
}

\author{
Fei Han ${ }^{1 *}$, Jean-Jacques Bahain ${ }^{2}$, Chunru Liu ${ }^{1}$, Gongming Yin ${ }^{1}$
}

1 State Key Laboratory of Earthquake Dynamics, Institute of Geology, China Earthquake Administration, Beijing 100029, China (Tel: +86 1062009077 , Email: hanfei@ies.ac.cn)

2 Département de Préhistoire Muséum National d'Histoire Naturelle, UMR7194 du CNRS, 1, rue René Panhard 75013, Paris, France (bahain@mnhn.fr)

\begin{abstract}
Several mathematical models have been suggested to describe uranium migration kinetics for ESR dating of fossil tooth. In the present study, different U-uptake models were used to calculate ages for fossil teeth from two open-air Paleolithic sites in Nihewan Basin - Donggutuo and Hougou and compared with independent age control of the sites. For Donggutuo site, the results show that the ages of three teeth calculated by EU and AU models were much younger than magnetostratigraphic age. At Hougou site, two teeth from the top of Nihewan lacustrine deposits give the consistent EU and AU ages within errors but younger than sediment OSL age. This study indicates that mathematical modeling could not always give convincing results for the open-air sites, which may experience dramatic hydrological variations and high erosion rates.
\end{abstract}

Keywords: ESR/U-series method, fossil teeth, uranium migration model, Donggutuo site, Hougou site

\section{Introduction}

Electron spin resonance (ESR) dating of fossil teeth is a valuable dating tool for archaeological sites, especially of Middle and Lower Paleolithic age. However, due to the open system behaviors of uranium in each dental tissue (enamel, dentine and/or cementum), the uranium migration history needs to be considered in determination of the dose rates of tooth samples. Several uranium uptake models have been proposed in ESR dating of fossil teeth: the early uranium uptake (EU) model (U-accumulation shortly after tooth burial) and linear uranium uptake (LU) model (continuous and constant U-accumulation) were the two U-uptake models commonly used in early ESR dating studies of teeth (Ikeya, 1982; Grün and Stringer, 1991). The EU model could be thought as a closed system of uranium in teeth, it always gives an age younger than LU 
model, so the two model ages have been used to bracket the supposedly correct sample age (Wrinn and Rink, 2003). In the case of late uptake of uranium in tooth samples, a recent uptake model (RU) was proposed (Blackwell et al., 1992). In order to apply US-ESR model for tooth dating, Grün et al. (1988) suggested combining uranium series analysis with ESR measurement in the US-ESR model by the determination a U-uptake parameter $\mathrm{p}(\mathrm{p} \geqslant-1)$, which describes the uranium accumulation in dental tissues. As there is no pre-determined assumption for U-migration history, US-ESR could yield a more reliable ages than EU, LU and RU models, which corresponds to specific p-values: $\mathrm{p}=-1, \mathrm{p}=0$ and $\mathrm{p}=\infty$ respectively. The US-ESR model has already exhibited its potential in dating of early hominid sites, such as Swartkrans in South Africa (Curnoe et al., 2001) and Atapuerca Gran Dolina in Spain (Falguères et al., 1999), but limits were also demonstrated in Early Palaeolithic sites of Orce Basin, Spain (Duval et al., 2012a, 2012b). The main limitation is that the model does not allow ${ }^{230} \mathrm{Th} /{ }^{234} \mathrm{U}$ activity ratios in dental tissues of more than 1.04, while this is often observed in natural samples. To solve this limitation, an Accelerating Uptake (AU) model (Shao et al., 2012) was introduced for describing the U-uptake into dental tissue as an accelerating process. This model, with two parameters, initial uptake rate and acceleration of this uptake rate, is then able to reconstruct a process combining incorporation followed by leaching. An uptake parameter named n-value is introduced in AU model and corresponds to the ratio of these two parameters (Shao et al., 2012). When $\mathrm{n}=$ 0 , the U-uptake is equal to LU model and the U-system will evolve towards secular equilibrium state in the case of $n \geqslant 0$.

Grün (2000a) also proposed the CSUS model, assuming that the present day uranium in a sample was accumulated at the apparent U-series age within a short time span, and the measured uranium contents in dentine and enamel of the teeth are used to calculate the total dose during the apparent U-series ages. Since CSUS model describes an extreme case of U-migration, it gives the maximum possible age of the tooth for a given ESR and U-series data set. Although some other mathematical models of U-migration have been also suggested in ESR dating of fossil teeth (e.g. saturation uptake model (Ikeya et al., 1997) or D-A model (Millard and Hedges, 1996)), they all have their own limitations, and are not widely applied in dating studies. The mentioned U-uptake and leaching models above in ESR tooth dating are summarized in Table 1.

In this study, we used combined ESR and U-series methods with different U-uptake models mentioned above (EU, LU, and ESR/U-series (US and AU) models) to the teeth from two open-air Paleolithic sites in 
Nihewan Basin, China, Donggutuo and Hougou sites, which are well-constrained by independent dating methods, to test the reliability of these mathematical models in ESR dating.

\section{Materials and method}

Mammalian fossil teeth from two Paleolithic open-air sites in Nihewan Basin, Donggutuo and Hougou, were studied (Figure S1). The corresponding archaeological layers are well dated by magnetostratigraphy about 1.1 Ma (Wang et al., 2005; Ao et al., 2010) for Donggutuo site, and 363 \pm 14 ka by OSL method for Hougou site (Nian et al., 2013). In this work, combined ESR and U-series analyses were carried out with different U-uptake models for age calculation of the fossil tooth. The samples from Donggutuo and Hougou sites were all fragmental pieces, which may represent the distinguished taphonomic features of Nihewan Paleolithic sites (Wei Qi, personal communication). All samples present enamel and dentine tissues. The two dental tissues were separated mechanically with a dental drill, enamel surfaces was cleaned on both dentine

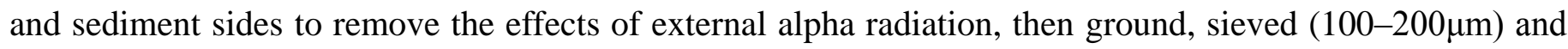
split into 15 aliquots for gamma irradiation from 125 to $50000 \mathrm{~Gy}$ for Donggutuo samples and 10 aliquots from 80 to 5000 Gy for Hougou samples with a calibrated ${ }^{60}$ Co GammaCell 220 research irradiator (LNHB, Saclay, France). U-series analyses were performed on each dental tissue of fine powder by $\alpha$-spectrometry for uranium concentration and radioisotopic ratios $\left({ }^{234} \mathrm{U} /{ }^{238} \mathrm{U}\right.$ and $\left.{ }^{230} \mathrm{Th} /{ }^{234} \mathrm{U}\right)$ measurement, following the procedure of Bischoff et al. (1988). Radon loss of both enamel and dentine was assessed from combined $\gamma$ and $\alpha$-spectrometry measurements (Bahain et al., 1992).

The ESR measurements were carried out on a Bruker EMX ESR spectrometer (X band, $9.82 \mathrm{GHz}$ ) at room temperature with the following acquisition parameters: $1 \mathrm{~mW}$ microwave power, 1024 points resolution, $100 \mathrm{kHz}$ modulation frequency, $0.1 \mathrm{mT}$ modulation amplitude, $20 \mathrm{~ms}$ conversion time and $5 \mathrm{~ms}$ time constant. Each sample was measured 4 times in order to check the reproducibility of the data.

The ESR intensity was extracted from peak-to-peak amplitudes (T1-B2) of the ESR signal of enamel (Grün, 2000b). In this study, the equivalent doses $\left(D_{E}\right)$ were determined by fitting the experimental data points using an exponential plus linear (EPL) function with Origin 8.0 software and $1 / \mathrm{I}^{2}$ weighting (Figure S2). The single saturation exponential (SSE) function, used commonly in the previous ESR dating studies of fossil teeth, cause $D_{E}$ overestimations for early Pleistocene samples (Duval et al., 2009). The double saturation exponential (DSE) function may better describe the analytical data points than conventional single 
saturation exponential (SSE) function (Duval et al., 2009, Han et al., 2011) but gives meaningless fitting parameters and much higher relative errors. As adjusted R-square (Adj. $\mathrm{R}^{2}$ ) values obtained by using EPL function are very close to DSE function and considering the lower relative errors of $\mathrm{D}_{\mathrm{E}}$ fitting results by EPL function (3\% to $8 \%$ for Donggutuo samples, and $22 \%$ to $30 \%$ for Hougou samples) and meaningful fitting parameters compared with DSE, we chose to use $D_{E}$ values of EPL fitting function for calculating the combined ESR/U-series age of fossil teeth.

The external $\gamma$-dose rate from the sediment was measured in situ by portable Canberra Inspector 1000 $\gamma$-spectrometer with a calibrated $\mathrm{NaI}$ detector. Since the fossil bearing lacustrine deposits are homogenous, there were no obvious dose rate changes in the culture layer of the same site. Sediments were also collected for $\mathrm{U}$, Th and $\mathrm{K}$ measurement to evaluate $\beta$-dose rate contribution in the laboratory of Department of Prehistory, MNHN, Paris with $\mathrm{HpGe} \gamma$-ray spectrometer at liquid nitrogen temperature. The sediment measured data were shown in the note of Table S1.

\section{Results and discussion}

The U-series analyses of both Donggutuo and Hougou sites show relatively high uranium concentrations in the enamel (Table S2), which range from 1.17 to $16.33 \mathrm{ppm}$, and between 72.82 and $143.69 \mathrm{ppm}$ in dentine. The ${ }^{234} \mathrm{U} /{ }^{238} \mathrm{U}$ ratios of enamel and dentine are similar, ranging from 1.75 to 2.10 and from 1.74 to 2.23, respectively. The ${ }^{230} \mathrm{Th} /{ }^{234} \mathrm{U}$ ratio ranges between 1.18 and 1.40 for enamel and from 1.35 to 1.75 for dentine, far beyond equilibrium, which indicate uranium leaching. In this case, US-ESR model cannot be applied for age calculation. Such limitations of US-ESR model were also observed during the study of Early Pleistocene sites in Orce Basin (Duval et al., 2012a). Since EU and LU models are two special cases of US-ESR model (EU model: $\mathrm{p}=-1$; LU model: $\mathrm{p}=0$ ), they also can only describe the uranium uptake instead of leaching, and are inappropriate for the age calculation of Donggutuo and Hougou teeth. The AU model can describe a process of uranium uptake followed by leaching, so in this study it is feasible for calculating sample ages. The dose rate and age results for the AU model calculations are shown in Table 2. The calculated $\mathrm{n}$ values from U-series and ESR data are all negative, as a result of uranium leaching. We place the EU and LU model ages in the Table 3 just for comparison.

The different components of dose rate contributed by dental tissues and surrounding environment are 
shown in Figure 1. For the three teeth from Donggutuo, the internal alpha dose rates were the main components of the total dose rate, ranges from $42 \%$ to $79 \%$; the beta dose rates from dentine are the second largest contributors to the total dose rate, between $13 \%$ and $33 \%$. The environmental dose rates from the sediments and cosmic rays vary between $8 \%$ and $25 \%$. For the two teeth from Hougou, both internal alpha dose rates and environmental dose rates made the largest contributions to the total dose rate, varying from $36 \%$ to $43 \%$ and $30 \%$ to $40 \%$ respectively. The beta dose rates from dentine contributed $24 \%$ to $27 \%$ to the total dose rate.

Comparing with the reference age of Donggutuo site $(\sim 1.1 \mathrm{Ma})$ constrained by palaeomagnetic study, both EU and AU model ages are much younger, and nearly 1/3 of the palaeomagnetic age for DGT0805 and DGT0807. This is probably attributed to the high uranium concentrations in the enamel of DGT0805 and DGT0807, both higher than $10 \mathrm{ppm}$. According to recent study by Joannes-Boyau and Grün (2011), the subsamples of tooth enamel with higher uranium concentration close to the dentine/enamel junction will yield smaller $D_{E}$ values than those with lower U-concentration close to the surface because of their higher concentrations of non-oriented $\mathrm{CO}_{2}^{-}$radicals generated by gamma irradiation. In this study, we did not observe this trend since we analyzed mixed enamel powder from both surface and dentine sides. In order to check whether the high uranium concentration caused alpha-efficiency variations, we introduced a k-value of zero into age calculation (Inverse correlation assumption, Bahain et al., 1992). The age results of both EU and AU models become consistent with the reference age within error. In this case, we could consider the high U-concentrations in enamel as the main reason for age underestimation.

For the Hougou teeth, calculated EU and AU model ages are slightly younger than the reference age obtained by OSL ( $360 \mathrm{ka}$, Nian et al., 2013) using the same calculation parameters of sediment (water content, U, Th and K content etc.) (Figure 2). Although LU model ages obtained in this study and by some scholars (Schwarcz et al., 1994) seems showing better agreement with other dating evidence, this simple U-uptake model does not have strong theoretical basis, and agreement with independent age control is purely incidental.

For Nihewan sites, the unexpected young ages seem related in part to the high U-content in enamel and to the high isotopic ratio, but we also could not exclude the effect of thermal instability of the ESR signal as well as a change of external dose rate related to the uplift and incision of the basin during the late 
Pleistocene period. Chen et al. (2001) studied early Pleistocene teeth from Longgupo Cave with isothermal annealing, and observed mixed first and second-order kinetics for radicals involved in the ESR enamel signal which may lead an age underestimation. More detailed studies by Joannes-Boyau and Grün (2011) found that the unstable non-oriented $\mathrm{CO}_{2}{ }^{-}$radicals (NOCORs) in tooth enamel could not be removed by post-irradiation heating or long storage times. This may cause significant age underestimation. However, their experiments are based on fragment analysis, and annealing protocols of powder studies need to be developed in order to assess the amount of unstable NOCORs of irradiated signal.

The two sites studied in this work are both open air sites. In the basin, a thick lacustrine layer was exposed to high erosion rates which were accompanied by variations of hydrological environments. The migration of uranium between ground water and dental tissues of is complex and may occur in multiple phases (Grün et al., 2014). Grün (2009b) showed that the p-values of teeth from open-air sites vary greatly. Therefore, for the fossil teeth from open air sites, it is not possible to make simple U-uptake assumptions for age calculation. Developed U-uptake models may work on some Late or Middle Pleistocene sites, however, they do not always give the reliable results for old sites if complex erosion occurred with repetitive uplift and incision processes. If possible, detailed U-isotopes mapping is indeed a useful and essential technique to better understand the U-mobilization in the teeth samples and facilitate the sample selection (Grün et al., 2014). Fossil teeth with high U-concentration in enamel and high ${ }^{230} \mathrm{Th} /{ }^{234} \mathrm{U}$ ratios in dental tissues should be avoided or abandoned since it is virtually impossible to obtain reliable ages regardless of the U-models used.

\section{Conclusion}

Combined ESR/U-series fossil dating has been applied on two open air sites Donggutuo and Hougou, in Nihewan Basin, China, and several commonly used U-migration models have been tested in this study. ESR/U-series models do have advantages on dating fossils from cave and fissure sites (Han et al., 2012; Shao et al., 2014), but this study also shows their limitation on dating of fossil teeth from open air sites. The ages calculated by EU and AU models are much younger than the references for Donggutuo site, and even if LU model ages agree with the reference occasionally for some samples, there is no theoretical basis of this parametric U-uptake model. This study indicates that the uranium migration models for combined ESR/U-series dating of fossil teeth from open sites are driven by the erosion and hydrological conditions of 
burial environment. Both simple and developed mathematic U-uptake (leaching) models are difficult to apply to old (Early Pleistocene) fossil tooth samples when the complexity of U-migration during the burial history cannot be reconstructed. For these open air samples, U-uptake/leaching model ages should be used with caution. Information of dramatic hydrological variation and erosion processes at the site should be investigated. Systematic uranium series isotopes mapping of dental tissues before sample preparation is highly recommended in order to abandon the high U-content enamel samples and better understand the uranium distribution and migration in the fossil teeth (Duval et al., 2011).

\section{Acknowledgement}

This study was part of the doctoral dissertation work of first author, which is supported by EGIDE PHC "Cai Yuanpei” Program (Project No. 24053YG). The work was also funded by State Key Laboratory of Earthquake Dynamics, Institute of Geology, China Earthquake Administration (Project No. LED2014A05) and National Science Foundation of China (Grant No. 41302139). We would like to thank Wei Qi from IVPP for his kindly help on the field, Tristan Garcia from LNHB for sample irradiation and Pierre Voinchet for helping in situ dose rate measurement. We also thank Rainer Grün for comments and language improvement, Shao Qingfeng for helping in AU age calculation and an anonymous referee for valuable discussion and comments.

\section{References}

Adamiec, G. and Aitken, M. J., 1998. Dose-rate conversion factors: update. Ancient TL 16, 37-50.

Ao, H., Deng, C., Dekkers, M. J., Liu, Q., Qin, L., Xiao, G., and Chang, H., 2010. Astronomical dating of the Xiantai, Donggutuo and Maliang Paleolithic sites in the Nihewan Basin (North China) and implications for early human evolution in East Asia. Palaeogeography, Palaeoclimatology, Palaeoecology 297, 129-137.

Bahain, J. J., Yokoyama, Y., Falguères, C., and Sarcia, M. N., 1992. ESR dating of tooth enamel - A comparison with K-Ar dating. Quaternary Science Reviews 11, 245-250.

Bischoff, J.L., Rosenbauer, R.J., Tavoso, A., de Lumley, H., 1988. A test of uranium-series dating of fossil tooth enamel: results from Tournal Cave, France. Applied Geochemistry 3, 145-151.

Blackwell, B., Porat, N., Schwarcz, H., and Debénath, A., 1992. ESR dating of tooth enamel: comparison with ${ }^{230} \mathrm{Th} /{ }^{234} \mathrm{U}$ speleothem dates at La Chaise-de-Vouthon (Charente), France. Quaternary Science Reviews 11, 231-244.

Chen, T., Chen, Q., Yang Q., and Hu, Y.Q., 2001. The problems in ESR dating of tooth enamel of Early Pleistocene and the age of Longgupo hominid, Wushan, China. Quaternary Science Reviews 20, 1041-1045.

Curnoe, D., Grun, R., Taylor, L., and Thackeray, F., 2001. Direct ESR dating of a pliocene hominin from Swartkrans. Journal of Human Evolution 40, 379-391.

Duval, M., Aubert, M., Hellstrom, J., and Grün, R., 2011. High resolution LA-ICP-MS mapping of U and 
Th isotopes in an early Pleistocene equid tooth from Fuente Nueva-3 (Orce, Andalusia, Spain). Quaternary Geochronology 6, 458-467.

Duval, M., Falguères, C., and Bahain, J.-J., 2012a. Age of the oldest hominin settlements in Spain: contribution of the combined U-series/ESR dating method applied to fossil teeth. Quaternary Geochronology 10, 412-417.

Duval, M., Falguères, C., Bahain, J.-J., Grün, R., Shao, Q., Aubert, M., Dolo, J.-M., Agustí, J., Martínez-Navarro, B., and Palmqvist, P., 2012b. On the limits of using combined U-series/ESR method to date fossil teeth from two Early Pleistocene archaeological sites of the Orce area (Guadix-Baza basin, Spain). Quaternary Research 77, 482-491.

Duval, M., Grün, R., Falguères, C., Bahain, J. J., and Dolo, J. M., 2009. ESR dating of Lower Pleistocene fossil teeth: Limits of the single saturating exponential (SSE) function for the equivalent dose determination. Radiation Measurements 44, 477-482.

Falguères, C., Bahain, J. J., Yokoyama, Y., Arsuaga, J. L., de Castro, J. M. B., Carbonell, E., Bischoff, J. L., and Dolo, J. M., 1999. Earliest humans in Europe: the age of TD6 Gran Dolina, Atapuerca, Spain. Journal of Human Evolution 37, 343-352.

Grün, R., 2000a. An alternative model for open system U-series/ESR age calculations: (closed system U-series)-ESR, CSUS-ESR. Ancient TL 18, 1-4.

Grün, R., 2000b. Methods of dose determination using ESR spectra of tooth enamel. Radiation Measurements 32, 767-772.

Grün, R., 2009a. The DATA program for the calculation of ESR age estimates on tooth enamel. Quaternary Geochronology 4, 231-232.

Grün, R., 2009b. The relevance of parametric U-uptake models in ESR age calculations. Radiation Measurements 44, 472-476.

Grün, R. and Katzenberger-Apel, O., 1994. An alpha irradiator for ESR dating. Ancient TL 12, 35-38.

Grün, R. and Schwarcz, H. P., 1988. Electron spin resonance dating of tooth enamel - Coupled correction for U-uptake and U-series disequilibrium. Nuclear Tracks and Radiation Measurements 14, 237-241.

Grün, R. and Stringer, C. B., 1991. Electron spin resonance dating and the evolution of modern humans. Archaeometry 33, 153-199.

Grün, R., Eggins, S., Kinsley, L., Moseley, H., and Sambridge, M., 2014. Laser ablation U-series analysis of fossil bones and teeth. Palaeogeography, Palaeoclimatology, Palaeoecology 416, 150-167.

Han, F., Bahain, J.-J., Boëda, É., Hou, Y., Huang, W., Falguères, C., Rasse, M., Wei, G., Garcia, T., and Shao, Q., 2012. Preliminary results of combined ESR/U-series dating of fossil teeth from Longgupo cave, China. Quaternary Geochronology 10, 436-442.

Han, F., Yin, G.M., Bahain, J.-J., Garcia, T., Liu, C.R., Gao, L., Li, J.P., 2011. The influence of different fitting functions on paleodose determination - Taking Longgupo tooth fossils as an example. Nuclear Techniques 34 (2), 116-120. (in Chinese with English abstract)

Ikeya, M., 1982. A model of linear uranium accumulation for ESR age of Heidelberg (Mauer) and Tautavel bones. Japanese Journal of Applied Physics 21, L690.

Ikeya, M., Ochiai, H., and Tani, A., 1997. Total dose (TD) formula for uranium saturation-uptake model for ESR and TL dating. Radiation Measurements 27, 339-343.

Joannes-Boyau, R. and Grün, R., 2011. A comprehensive model for $\mathrm{CO}_{2}{ }^{-}$radicals in fossil tooth enamel: Implications for ESR dating. Quaternary Geochronology 6, 82-97.

Marsh, R.E., Prestwich, W.V., Rink, W.J., and Brennan, B.J., 2002. Monte Carlo determinations of the beta dose rate to tooth enamel. Radiation Measurements 35, 609-616.

Millard, A. R. and Hedges, R. E. M., 1996. A diffusion-adsorption model of uranium uptake by archaeological bone. Geochimica et Cosmochimica Acta 60, 2139-2152.

Nian, X. M., Zhou, L. P., and Yuan, B. Y., 2013. Optically stimulated luminescence dating of terrestrial sediments in the Nihewan Basin and its implication for the evolution of ancient Nihewan lake. Quaternary Sciences 33, 403-414. (in Chinese with English Abstract)

Rae, A. M. and Ivanovich, M., 1986. Successful application of uranium series dating of fossil bone. Applied geochemistry 1, 419-426.

Shao, Q., Bahain, J.-J., Falguères, C., Dolo, J.-M., and Garcia, T., 2012. A new U-uptake model for combined ESR/U-series dating of tooth enamel. Quaternary Geochronology 10, 406-411.

Shao, Q., Wang, W., Deng, C., Voinchet, P., Lin, M., Zazzo, A., Douville, E., Dolo, J.-M., Falguères, C., and Bahain, J.-J., 2014. ESR, U-series and paleomagnetic dating of Gigantopithecus fauna from 
Chuifeng Cave, Guangxi, southern China. Quaternary Research 82, 270-280.

Wang, H. Q., Deng, C. L., Zhu, R. X., Wei, Q., Hou, Y. M., and Boeda, E., 2005. Magnetostratigraphic dating of the Donggutuo and Maliang Paleolithic sites in the Nihewan Basin, North China. Quaternary Research 64, 1-11.

Wrinn, P. and Rink, W. J., 2003. ESR dating of tooth enamel from Aterian levels at Mugharet el 'Aliya (Tangier, Morocco). Journal of archaeological science 30, 123-133.

\section{Figure captions:}

Figure 1 Percentage contribution by $\alpha, \beta, \gamma$ and cosmic dose rates to the total dose rate of Donggutuo and Hougou teeth samples

Figure 2 Comparison of three U-uptake (leaching) model ages with independent age control (the shade of blue indicates the reference age by paleomagnetic and astronomical dating methods (Wang et al., 2005; Ao et al., 2010); the red one brackets the range of reference age by OSL dating (Nian et al., 2013) )

\section{Table captions:}

Table 1 Different uranium migration models for ESR fossil dating

Table 2 Dose rate components calculated with AU model by combined ESR/U-series analysis

Table 3 Sample ages calculated with different U-uptake (leaching) models. 


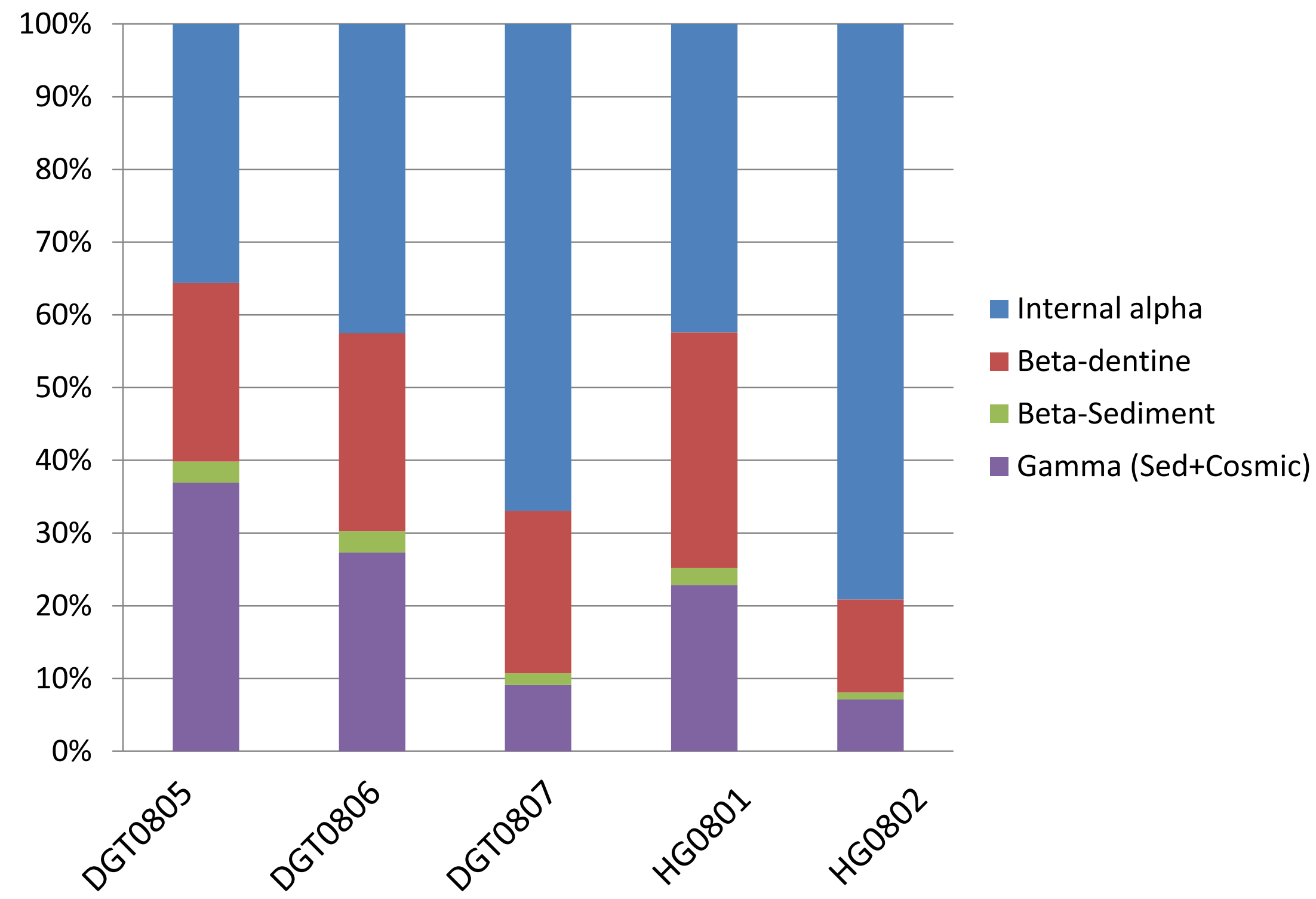

Figure 1Percentage contribution by $\alpha, \beta, \gamma$ and cosmic dose rates to the total dose rate of Donggutuo and Hougou teeth samples 
Age (ka)

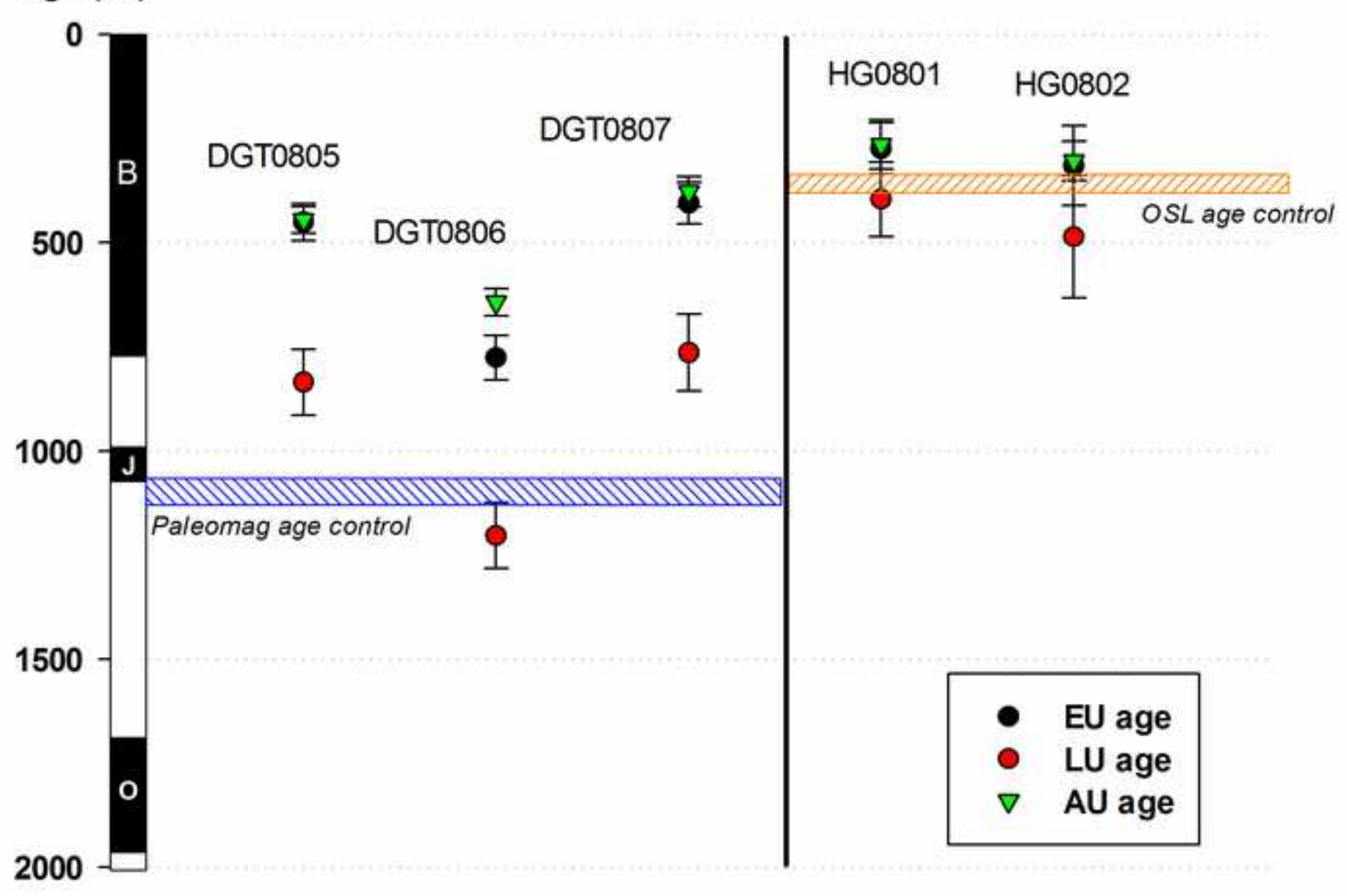


Table 1 Different uranium migration models for ESR fossil dating

\begin{tabular}{|c|c|c|c|c|c|}
\hline Models & Description & Expression & Diagram & Limitation & References \\
\hline $\begin{array}{l}\text { Early uptake } \\
\text { (EU-ESR) } \\
\text { model }\end{array}$ & $\begin{array}{l}\text { Uranium accumulated } \\
\text { shortly after } \\
\text { tooth burial }\end{array}$ & $\begin{array}{l}U(t)=U_{m} \\
U(t) \text { - U concentration at any time t; } \\
U_{m} \text { - maximum } U \text { concentration; } \\
\mathrm{T} \text { - the age of tooth sample }\end{array}$ & $\stackrel{\Xi}{\supset}$ & $\begin{array}{c}\text { Artifical assumption, ideal } \\
\text { case based on geochemical } \\
\text { process of uranium }\end{array}$ & $\begin{array}{c}\text { Rae and Ivanovich, } \\
1986\end{array}$ \\
\hline $\begin{array}{c}\text { Linear } \\
\text { uptake } \\
\text { (LU-ESR) } \\
\text { model }\end{array}$ & $\begin{array}{l}\text { Uranium accumulated } \\
\text { continously } \\
\text { after tooth burial }\end{array}$ & $\begin{array}{l}U(t)=U_{m}(t / T) \\
* \text { same parameters as in EU }\end{array}$ & $\stackrel{\Xi}{5} \bigsqcup_{0}^{U_{m}}$ & $\begin{array}{c}\text { Artifical assumption, based } \\
\text { on experiences }\end{array}$ & $\begin{array}{c}\text { Ikeya, } \\
1982\end{array}$ \\
\hline $\begin{array}{l}\text { U-series ESR } \\
\text { (US-ESR) } \\
\text { model }\end{array}$ & $\begin{array}{l}\text { Uranium accumulated } \\
\text { as a function of time, } \\
\text { depending on a } \\
\text { parameter } \mathrm{p}\end{array}$ & $\begin{array}{l}U(t)=U_{m}(t / T)^{p+1} \\
* \text { same parameters as in EU; } \\
\text { uptake parameter } p \geq-1 \\
(p=-1 \rightarrow E U ; p=0 \rightarrow \mathrm{LU})\end{array}$ & $\underbrace{U_{m}}$ & $\begin{array}{c}\text { No solution in the case of } \\
\text { U-leaching }\end{array}$ & $\begin{array}{l}\text { Grun et al., } \\
1988\end{array}$ \\
\hline $\begin{array}{c}\text { Recent } \\
\text { uptake } \\
\text { (RU-ESR) } \\
\text { model }\end{array}$ & $\begin{array}{l}\text { Uranium accumulated } \\
\text { shortly and } \\
\text { recently }\end{array}$ & $\begin{array}{l}U(t)=U_{m}(t / T)^{2} \\
* \text { same parameters as in EU }\end{array}$ & $\underbrace{U_{m}}_{0}$ & $\begin{array}{l}\text { Artifical assumption, only } \\
\text { yield maximum age limit }\end{array}$ & $\begin{array}{c}\text { Blackwell et al., } \\
1992\end{array}$ \\
\hline $\begin{array}{l}\text { Close-system } \\
\text { U-series ESR } \\
\text { (CSUS-ESR) } \\
\text { model }\end{array}$ & $\begin{array}{l}\text { Uranium accumulated } \\
\text { instantly at the time of } \\
\text { the apparent } \\
\text { U-series date }\end{array}$ & $\begin{array}{l}\boldsymbol{U}\left(\boldsymbol{t}_{\boldsymbol{a}}\right)=\boldsymbol{U}_{\boldsymbol{m}} \\
\mathrm{t}_{\mathrm{a}}-\text { apparent U-series age of tooth } \\
\text { sample }\end{array}$ & $\underbrace{U_{m}}_{0}$ & $\begin{array}{l}\text { An open system model } \\
\text { provide a maximum } \\
\text { possible age }\end{array}$ & $\begin{array}{l}\text { Grun et al., } \\
\quad 2000\end{array}$ \\
\hline $\begin{array}{l}\text { Accelerating } \\
\text { uptake } \\
\text { (AU-ESR) } \\
\text { model }\end{array}$ & $\begin{array}{l}\text { Uranium accumulated } \\
\qquad \text { as an } \\
\text { accelerating process }\end{array}$ & $\begin{array}{l}d U_{8} / d t=f_{8} / \lambda_{8}+a_{8} t / \lambda_{8} \rightarrow U_{8}(t)= \\
f_{8} / \lambda_{8}\left(n / 2 \cdot t^{2}+t\right) \\
\mathrm{U}_{8}-{ }^{238} \mathrm{U} \text { content at any time } \mathrm{t} ; \\
\lambda_{8}-\text { decay constant of }{ }^{238} \mathrm{U} ; \\
\mathrm{f}_{8}-\text { initial uptake rate of }{ }^{238} \mathrm{U} ; \\
\mathrm{a}_{8}-\text { accelerations of } \mathrm{f}_{8} ; \\
\mathrm{n}-\mathrm{a}_{8} / \mathrm{f}_{8}\end{array}$ & $\prod_{0}^{ \pm}$ & $\begin{array}{c}\text { Applied to moderate } \\
\text { U-leaching case; discussed } \\
\text { in this study }\end{array}$ & $\begin{array}{l}\text { Shao et al., } \\
\quad 2012\end{array}$ \\
\hline
\end{tabular}


Table 2 Dose rate components calculated with AU model by combined ESR/U-series analysis

\begin{tabular}{|c|c|c|c|c|c|c|c|c|}
\hline $\begin{array}{c}\text { Sample } \\
\text { No. }\end{array}$ & $\begin{array}{c}\gamma \\
\text { sediment+ } \\
\text { cosmic } \\
(\mu \mathrm{Gy} / \mathbf{a})\end{array}$ & $\begin{array}{c}\text { Internal dose } \\
(\alpha+\beta) \text { enamel } \\
\quad(\mu \mathrm{Gy} / \mathbf{a})\end{array}$ & $\begin{array}{c}\beta \text { dentine } \\
(\mu \mathrm{Gy} / \mathbf{a})\end{array}$ & $\begin{array}{c}\beta \\
\text { sediment } \\
(\mu \mathrm{Gy} / \mathbf{a})\end{array}$ & $\begin{array}{c}\text { Total dose } \\
\text { rate }(\mu G y / a)\end{array}$ & N-enamel & N-dentine & $\begin{array}{c}\text { AU-ESR age } \\
\text { (ka) }\end{array}$ \\
\hline DGT0805 & $1052 \pm 105$ & $7721 \pm 988$ & $2579 \pm 330$ & $183 \pm 18$ & $11535 \pm 1047$ & $-0.0031 \pm 0.00026$ & $-0.0032 \pm 0.00027$ & $445 \pm 32$ \\
\hline DGT0806 & $1052 \pm 105$ & $1949 \pm 199$ & $1491 \pm 152$ & $107 \pm 11$ & $4599 \pm 270$ & $-0.0021 \pm 0.00012$ & $-0.0022 \pm 0.00013$ & $643 \pm 33$ \\
\hline DGT0807 & $1052 \pm 105$ & $11694 \pm 1849$ & $1895 \pm 300$ & $141 \pm 15$ & $14782 \pm 1876$ & $-0.0037 \pm 0.00043$ & $-0.0039 \pm 0.00044$ & $378 \pm 36$ \\
\hline HG0801 & $925 \pm 93$ & $892 \pm 636$ & $615 \pm 438$ & $73 \pm 8$ & $2505 \pm 779$ & $-0.0058 \pm 0.0016$ & $-0.0061 \pm 0.0016$ & $265 \pm 59$ \\
\hline HG0802 & $925 \pm 93$ & $1440 \pm 600$ & $921 \pm 383$ & $100 \pm 10$ & $3386 \pm 719$ & $-0.0046 \pm 0.00091$ & $-0.0049 \pm 0.00092$ & $304 \pm 47$ \\
\hline
\end{tabular}

*Note: The AU-ESR ages of the samples were calculated using a program based on MATLAB software (Shao et al., 2012) with the following parameters and assumptions: alpha efficiency of $0.13 \pm 0.02$ (Grün and Katzenberger-Apel, 1994); dose rate conversion factors of Adamiec and Aitken (1998);

Monte-Carlo beta attenuation factors (Marsh et al., 2002) based on the thickness of the enamel layer, before and after its preparation; water contents of 3 $\mathrm{wt} \%$ in the enamel, $7 \mathrm{wt} \%$ in the dentine and $15 \mathrm{wt} \%$ in sediment were assumed. 
Table 3 Sample ages calculated with different U-uptake (leaching) models

\begin{tabular}{ccccc}
\hline $\begin{array}{c}\text { Sample } \\
\text { No. }\end{array}$ & $\begin{array}{c}\text { EU age } \\
\text { (ka) }\end{array}$ & $\begin{array}{c}\text { LU age } \\
(\mathbf{k a})\end{array}$ & $\begin{array}{c}\text { AU age } \\
(\mathbf{k a})\end{array}$ & Reference age \\
\hline \hline DGT0805 & $451 \pm 44$ & $835 \pm 79$ & $445 \pm 32$ & \\
DGT0806 & $776 \pm 54$ & $1204 \pm 79$ & $643 \pm 33$ & $1.06 \sim 1.12 \mathrm{Ma}$ \\
DGT0807 & $405 \pm 50$ & $764 \pm 92$ & $378 \pm 36$ & \\
\hline HG0801 & $274 \pm 62$ & $396 \pm 90$ & $265 \pm 59$ & \multirow{2}{*}{$363 \pm 14 \mathrm{ka}$} \\
HG0802 & $315 \pm 95$ & $486 \pm 147$ & $304 \pm 47$ & \\
\hline
\end{tabular}

*Note: EU, LU ages were calculated with DATA program (Grün, 2009a) with the same parameters as in the note of Table 2. 